\title{
Experimental Studies of Emissions in a Cl Engine Blended with Refined Sunflower Oil
}

\author{
J. Hemanandh ${ }^{1}$ and K. V. Narayanan ${ }^{2 *}$ \\ 'Department of Mechanical Engineering, Asst. Professor, Sathyabama University, \\ Chennai, TN, India; hema_3_2000@yahoo.com \\ ${ }^{2}$ Department of Mechanical Engineering, Professor, Sathyabama University, TN, \\ Chennai, India; k_v_narayanan@hotmail.com
}

\begin{abstract}
The present study analyzes emissions, by using different blends of diesel and Refined Sunflower oil (RSF) on Kirloskar Direct Injection 4-stroke Diesel engine, single cylinder air-cooled, $4.4 \mathrm{~kW}$, constant speed at $1500 \mathrm{rpm}$, compression ratio 17.5:1, Methyl Esters of refined sunflower oil (BRS) was transesterified with sodium meth oxide before blending with diesel. The main objective of this study is to measure the $\mathrm{NO}_{\mathrm{x}^{\prime}} \mathrm{CO}, \mathrm{HC}$, and Exhaust temperature by varying the Injection pressure and the load. The experiments were conducted with various blends of diesel (BRS10, BRS30, and BRS40) at different pressures (180 bar, 210 bar, \& 240 bar) and at different loads ( $0 \%, 25 \%, 50 \%, 75 \%, 100 \%)$. A 3-hole nozzle was used to inject the fuel. The Emission results were studied using AVL gas analyzer. The results show that there is an increase in $\mathrm{CO}$, marginal increase in $\mathrm{NO}_{\mathrm{x}}$ and decrease in $\mathrm{HC}$.
\end{abstract}

Keywords: Kirloskar Di-Diesel Engine, Injection Pressure, BRS-Biodiesel Refined Sunflower Oil, 3-hole Nozzle, Combustion Emission Characteristics.

\section{Introduction}

In the Present scenario, the depleting fossil petroleum fuel, with ever increase in fuel price and increase in pollution level hazards to the environment that results due to engine exhaust, forces the usage of alternate fuels. Biodiesel or vegetable oil is eco-friendly and greatly reduce the greenhouse emissions and it is the available choice in comparison with diesel fuel.

The vegetable oils cannot be used directly along with diesel, since it is highly viscous. Transesterification process is done in the presence of methanol, and Sodium methoxide as catalyst. This improves the performance of the engine and reduces the emissions.

\subsection{Background}

Similar experiments on biodiesel were conducted by many researchers. Literature on biodiesel experiments by Yin et al. [1] shows that methanol with catalyst produces high yield in shorter time which results in UIMS \& PUI than MS \& FPUI containing lesser quantity catalyst and less energy consumption. In hydro conversion of SF oil Raney Nickel catalyst was investigated by Onyestyak et al. [2] and also tested with some of the octanoic acid as model and compounded at 21 bar in the temperature of $280^{\circ} \mathrm{C}$ to $340^{\circ} \mathrm{C}$, in addition of $\ln _{2} \mathrm{O}_{2}$ significantly resulted in high alcohol yields. The combustion and emission results in base line fuel and the emission of smoke and nitrogen oxide measured at the engine exhaust while using cottonseed or sunflower oil in different proportions with two speeds and 3 loads tested by Rakopoulos et al. [3] the blends of sunflower, cotton seed, corn and olive used in six cylinders turbo charged heavy duty DI, Mercedes benz mini bus engine with the amount of two speed and three load conditions with neat diesel resulted in no changes in the thermal efficiency,

* Corresponding author:

K. V. Narayanan (k_v_narayanan@hotmail.com) 
reduction of smoke and insignificant increase in $\mathrm{NO}_{\mathrm{x}}$. Shehata [4] conducted experiments on Sunflower oil and Jajoba oil with $80 \%$ Pd by varying different engine speed resulted in lower brake thermal efficiency, smoke, $\mathrm{CO}$ and $\mathrm{HC}$.

The experiments on the DI diesel Perkinson engine were conducted by Dorado et al. [5] by using reused olive oil methyl ester to study the effect on combustion efficiency. As a result, oxygen concentration was increased and accelerated the combustion. It was also found that the rate of combustion efficiency in the use of reused olive oil, methyl esters, and the rate of combustion efficiency remains almost constant as in the use of diesel oil. A lower energy rate was showed in the palm oil combustion, done by Tashtoush et al. [6] It was more efficient and higher rate of combustion (66\%) seen in burning biodiesel, and the same for diesel combustion is $56 \%$. This is because of the properties like high viscosity, less volatility with density. Sudhir et al. [7] conducted test on Diesel Engine, and the rate of combustion temperature and pressure was low in the operation of biodiesel, and the $\mathrm{NO}_{\mathrm{x}}$ emissions was also almost to that of diesel. The sulphate emission was very low due to the lesser level of sulphur. The pilot combustion caused the precombustion. The observation was that the blending ratio of $15 \%$ resulted in reduced smoke opacity. The test conducted in DI stationary engine by Yusuf et al. [8] showed that as the blend increases, the brake power and $\mathrm{CO}$ increases in variable speed which was lesser than $1800 \mathrm{rpm}$. A review was done by Shereena et al. [9] using catalyst along with methanol in the transesterification process, which results in varying fatty acid content of the biodiesel. This could be a good alternative fuel for diesel.

\subsection{Methodology}

The Density, Kinematic viscosity of the BRS is within the limits of the Biodiesel Standards. It is estimated that the calorific value of the BRS is lesser when compared with diesel. The Engine requires a modification to improve emission reduction. The flash point of the BRS is high about $254^{\circ} \mathrm{C}$ compared with pure diesel and is safe to store and transport. The properties of the Diesel, Biodiesel standards \& BRS as shown in Table 3.

The aim of the work is to analyze emissions and to study the performance of the Diesel engine by using biodiesel. This has been done by changing the injection pressure, fuelled with transesterified refined sunflower oil combined with pure diesel at different blends (BRS10, BRS30, and BRS40).

\subsection{Nomenclature}

BRS _ Biodiesel Refined Sunflower oil

PD - Pure Diesel

$\rho \quad$ - Density, $\mathrm{kg} / \mathrm{m} 3$

$\mathrm{L} \quad-\quad$ Length, $\mathrm{mm}$

BP - Brake power, $\mathrm{kW}$

$\mathrm{N} \quad-\quad$ Engine running speed, $\mathrm{rpm}$

$\mathrm{T}$ - Torque, $\mathrm{N}-\mathrm{m}$

$\mathrm{CV} \quad-\quad$ Calorific Value of the fuel, $\mathrm{kJ}$

$\mathrm{R} \quad-\quad$ Radius of the drum, $\mathrm{mm}$

A $\quad-$ Area of the piston, $\mathrm{mm}^{2}$

K - - No. of cylinders

BIS - Bureau of Indian standards

ASTM - American standards of Testing and Materials

\section{Methodology}

\subsection{Transesterification Process}

The Methyl esters are formed by transesterification process. One litre of refined sunflower oil is treated with $400 \mathrm{~g}$ of methanol and $30 \mathrm{~g}$ of Sodium methoxide as catalyst. During the first phase oil is heated to raise of $20^{\circ} \mathrm{C}$ to $30^{\circ} \mathrm{C}$ from the room temperature and is allowed to cool naturally. For production of pure methyl ester, without any soap content, methanol is added to the preheated oil with catalyst at cold temperature and the mixture is heated to the order of $70^{\circ} \mathrm{C}$ to $80^{\circ} \mathrm{C}$ during the transesterification process of oil to reduce viscosity.

$\begin{array}{llll}\mathrm{CH}_{2} \mathrm{OCOR} & & \begin{array}{l}\mathrm{CH}_{2} \mathrm{OH} \\ \mathrm{I}\end{array} & \mathrm{RCOOR} \\ \mathrm{CH}_{2} \mathrm{OCOR}+3 \mathrm{ROH} & \stackrel{\mathrm{I}}{\text { catalyst }} \longrightarrow & \mathrm{CH}_{2} \mathrm{OH}+\mathrm{RCOOR} \\ \mathrm{I} & & \mathrm{I} & \\ \mathrm{CH}_{2} \mathrm{OCOR} & & \mathrm{CH}_{2} \mathrm{OH} & \text { RCOOR } \\ \text { Transesterification Alcohol Catalyst } & \text { Glycerin } & \text { Methyl Esters }\end{array}$

\subsection{Table 1. Specification of Test Engine}

Type

Combustion

Rated Power

Rated Speed

Compression Ratio

Injector type

Fuel injection pressure

Dynamometer
Kirloskar Vertical, 4S, Single acting, High speed, C.I. Diesel Engine Direct Injection $4.3 \mathrm{~kW}$ $1500 \mathrm{rpm}$ 17.5:1 Single, 3-hole jet injector 210 bar Eddy current 


$\begin{array}{lll}\text { Dynamometer arm length } & : & 200 \mathrm{~mm} \\ \text { Bore } & : & 87.5 \mathrm{~mm} \\ \text { Stroke } & : & 110 \mathrm{~mm} \\ \text { Connecting Rod } & : & 200 \mathrm{~mm} \\ \text { Cubic Capacity } & : & 661.5 \mathrm{~cm}^{3} \\ \text { Maximum Torque } & : & 0.030 \mathrm{kN}-\mathrm{m} \text { (full load @ } \\ & & 1500 \mathrm{rpm}) \\ \text { Fuel tank Capacity } & : & 6.5 \text { liters } \\ \text { Injection pump type } & : & \text { Single cylinder flange } \\ & & \begin{array}{l}\text { mounted without } \\ \text { camshaft } \\ \text { Mechanical centrifugal } \\ \text { Governor type }\end{array} \\ & : & \end{array}$

\subsection{Table 2. Details of Measuring Systems}

1. AVL Pressure Transducer GH 12 D

2. Software Version V $2.0 \quad$ - $\quad$ AVL 617 Indi meter

3. Data Analyzer from Engine

- $\quad$ AVL PIEZO CHARGE AMPLIFIER

4. To measure pressure _ $\quad$ - AVL 364 Angle Encoder

5. Smoke meter _ $\quad$ AVL 437 C Smoke

6. 5 Gas Analyzer $\left(\mathrm{NO}_{\mathrm{x}}, \mathrm{HC}, \mathrm{CO}, \mathrm{CO}_{2}, \mathrm{O}_{2}\right) \quad$ - $\quad$ AVL DIGAS 444 Analyzer

\subsection{Experimental Setup}

A stationary kirloskar 4S, DI Diesel Engine was used for conducting experiments. The specification of the engine

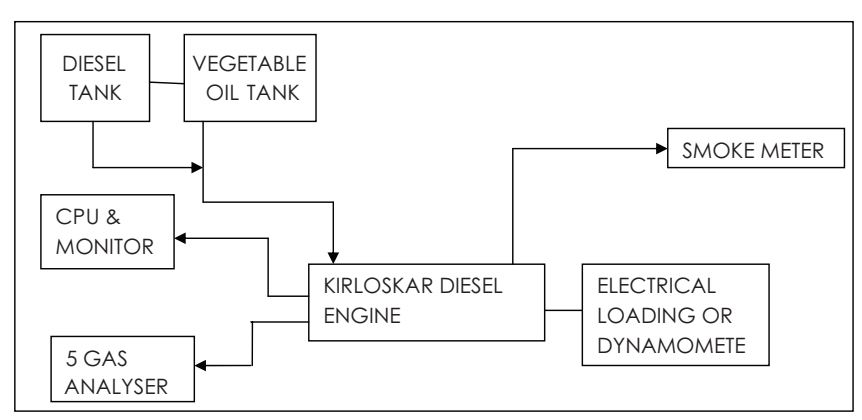

Figure 1. Schematic Diagram of Experimental set-up.

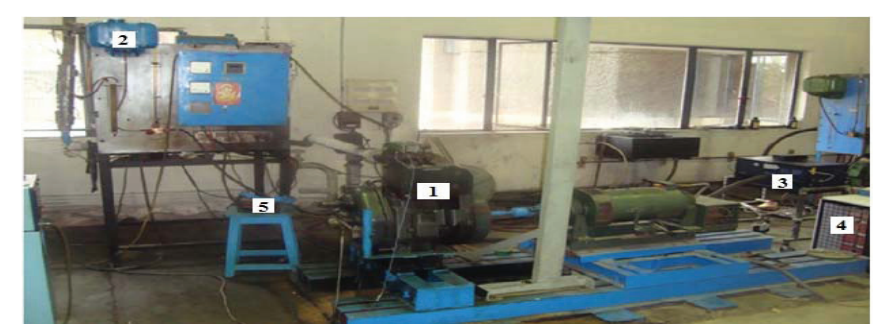

1 - Kirloskar Vertical C.I. Diesel Engine, 2 - Fuel Tank, 3 - AVL 437 C Smoke meter, 4 - Electrical loading device, 5 - Engine temperature monitor. is given in Table 1. The load on the engine was applied using Electrical loading (Dynamometer). The Eddy current dynamometer for loading is coupled to the engine for different loading $(0 \%, 25 \%, 50 \%, 75 \%, 100 \%)$ conditions. The exhaust gas emissions from the engine was measured using AVL DIGAS 444 Analyser $\left(\mathrm{NO}_{\mathrm{x}}\right.$, $\mathrm{HC}$, $\mathrm{CO}, \mathrm{CO}_{2}, \mathrm{O}_{2}$ ) and the smoke opacity was measured using AVL 437C smoke meter. AVL 364 Angle Encoder was used to measure the pressure and crank angle as given in Table 2.

\subsection{Test Procedure}

The experiments were conducted at different load conditions, with different pressures at different blends viz $(10 \%$ BRS + 90\% PD), (30\% BRS + 70\% PD), (40\% BRS + $60 \% \mathrm{PD})$ as fuel. The test was conducted at a constant speed of $1500 \mathrm{rpm}$. The engine was allowed to run at no load cndition for 10 minutes, using each proportion of the blend before applying the load. The loads were increased gradually for each blend in steps of $25 \%$ at constant speed of $1500 \mathrm{rpm}$ at different pressures. The objective is to analyze the emissions based on the above conditions. The schematic diagram of Experimental setup as shown in Figure 1.

\subsection{Table 3. Comparison of Properties of} Diesel, Biodiesel Standards \& BRS

\begin{tabular}{|c|c|c|c|c|c|}
\hline S.No. & Properties & Diesel & $\begin{array}{l}\text { BIS } \\
\text { Standard } \\
\text { Bio Diesel }\end{array}$ & $\begin{array}{c}\text { ASTM } \\
\text { D - 6751 } \\
(\text { IS } 15607: 2005)\end{array}$ & $\begin{array}{l}\text { Refined } \\
\text { Sunflower } \\
\text { oil }\end{array}$ \\
\hline 1. & $\begin{array}{l}\text { Cetane Index } \\
(\min )\end{array}$ & 46 & 51 & - & 38 \\
\hline 2. & $\begin{array}{l}\text { Density at } \\
15^{\circ} \mathrm{C} \mathrm{kg} / \mathrm{m} 3\end{array}$ & $820-845$ & $860-900$ & $(860-900 \mathrm{Kg} / \mathrm{m} 3)$ & 923 \\
\hline & Kinematic & & & & 28.3 \\
\hline 3. & $\begin{array}{l}\text { Viscosity at } 40 \\
{ }^{\circ} \mathrm{C} \text { cst }\end{array}$ & $2-4.5$ & $2.5-6$ & $1.9-6 \mathrm{~mm} 2 / \mathrm{s}$ & \\
\hline 4. & $\begin{array}{l}\text { Flash point } \\
{ }^{\circ} \mathrm{C} \text { min }\end{array}$ & $35^{\circ} \mathrm{C}$ & $262^{\circ} \mathrm{C}$ & $130^{\circ} \mathrm{C} \min$ & 254 \\
\hline 5. & $\begin{array}{l}\text { Calroific Value } \\
\mathrm{kJ} / \mathrm{kg}\end{array}$ & 44,000 & - & - & 39,284 \\
\hline 6. & $\begin{array}{l}\text { Water Content } \\
\mathrm{mg} / \mathrm{kg}\end{array}$ & 200 & 500 & $\begin{array}{c}0.050 \% \text { by mass, } \\
\max \end{array}$ & $0.05 \%$ \\
\hline 7. & $\begin{array}{l}\text { Copper strip } \\
\text { Corrosion } \\
3 \mathrm{hr} @ 100^{\circ} \mathrm{C} \\
(\max )\end{array}$ & 1 & $1 @ 50^{\circ} \mathrm{C}$ & No. 3 (Max) & No. 1 \\
\hline
\end{tabular}




\section{Results \& Discussions}

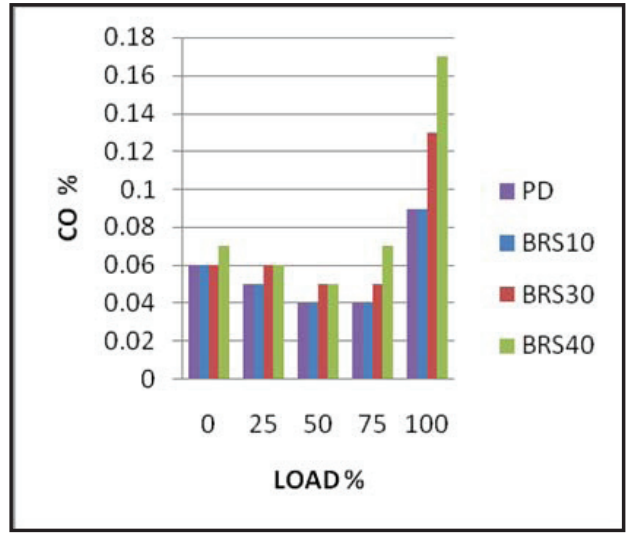

Figure 2. Variation of $\mathrm{CO}$ with respect to various blends of biodiesel at 180 bar.

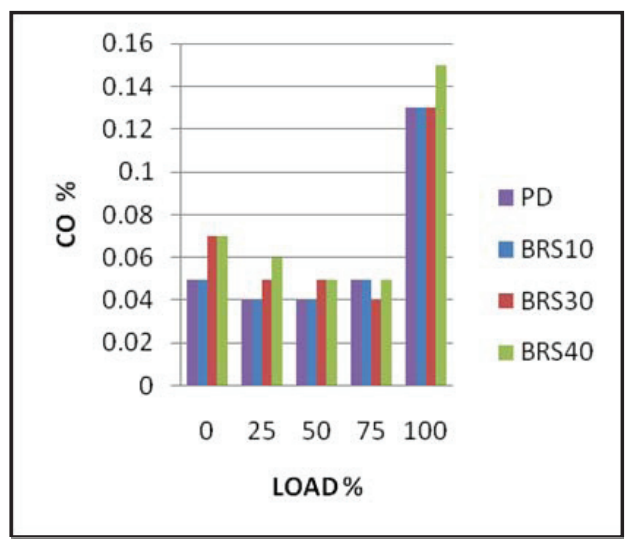

Figure 3. Variation of $\mathrm{CO}$ with respect to various blends of biodiesel at 210 bar.

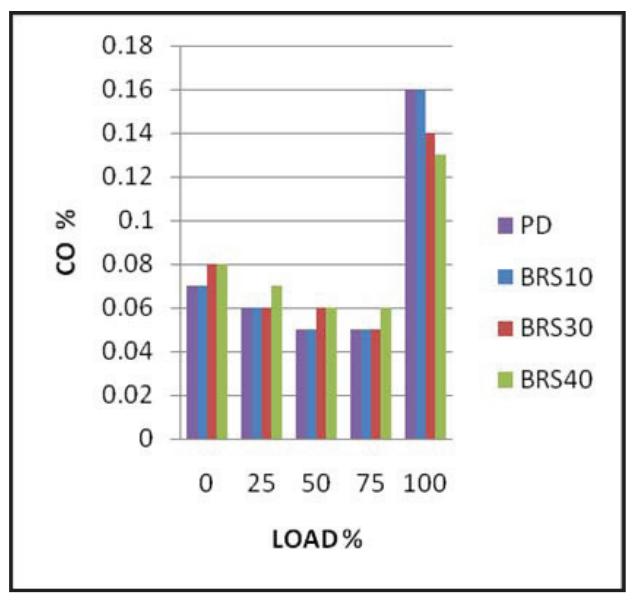

Figure 4. Variation of $\mathrm{CO}$ with respect to various blends of biodiesel at 240 bar.

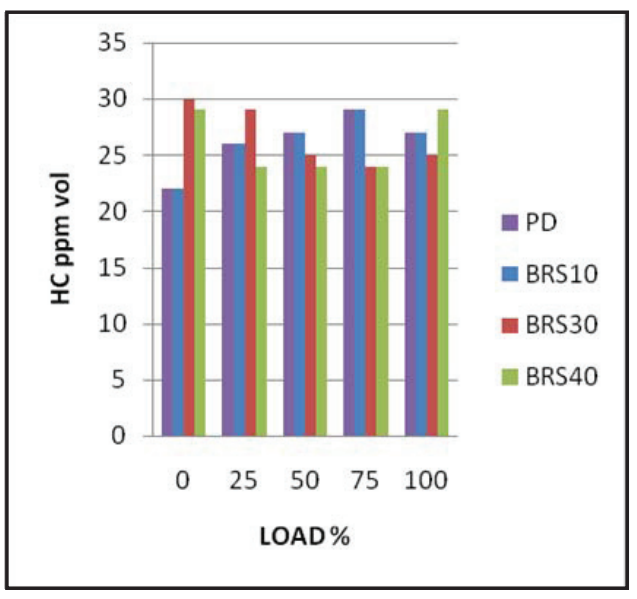

Figure 5. Variation of $\mathrm{HC}$ with respect to various blends of biodiesel at 180 bar.

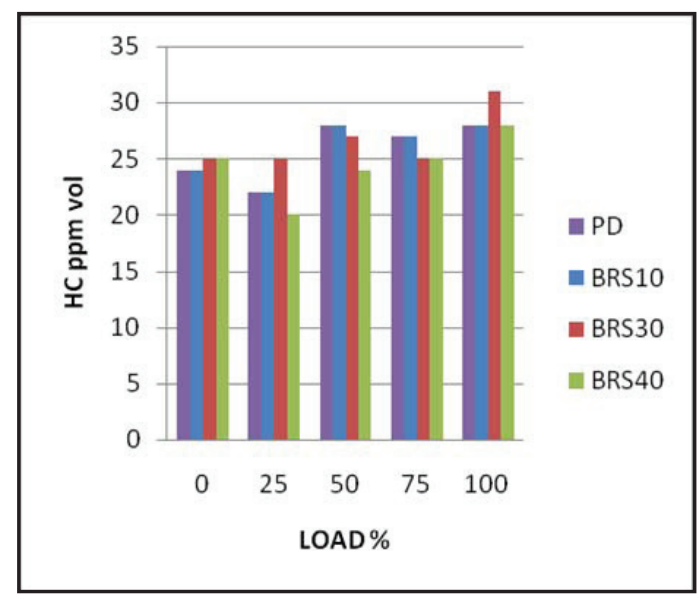

Figure 6. Variation of $\mathrm{HC}$ with respect to various blends of biodiesel at 210 bar.

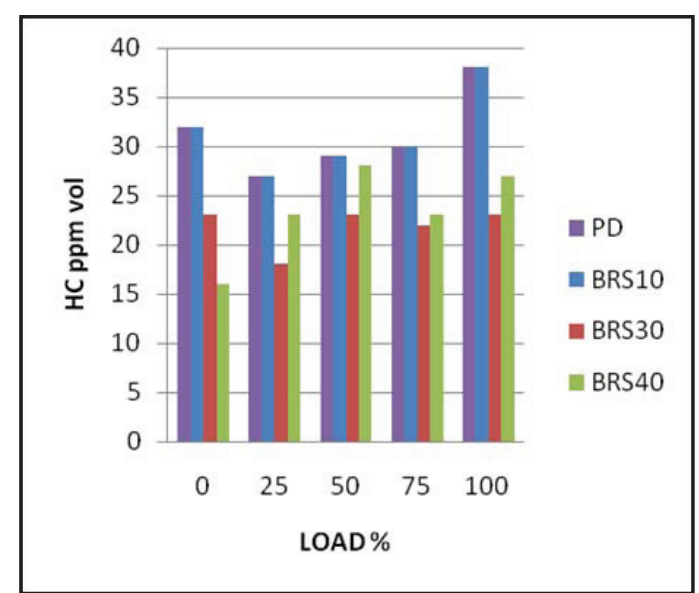

Figure 7. Variation of $\mathrm{HC}$ with respect to various blends of biodiesel at 240 bar. 


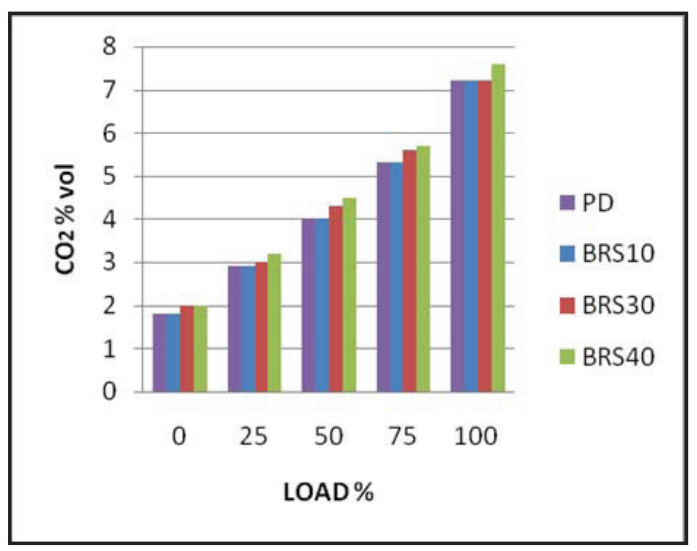

Figure 8. Variation of $\mathrm{CO} 2$ with respect to various blends of biodiesel at 180 bar.

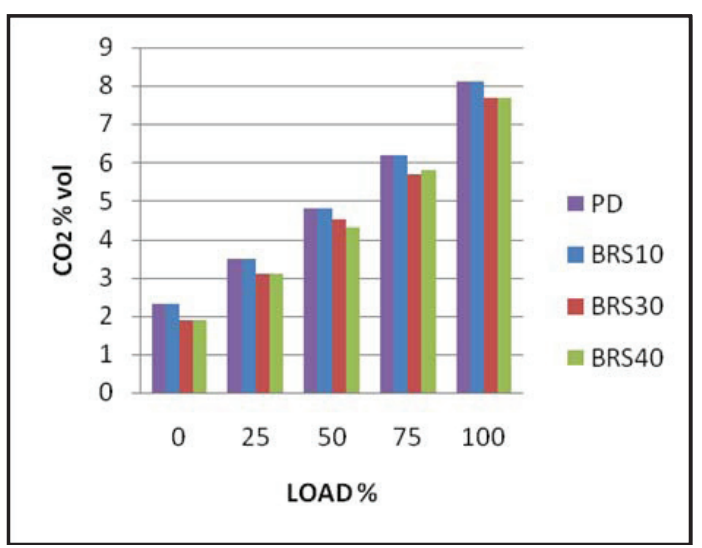

Figure 9. Variation of $\mathrm{CO} 2$ with respect to various blends of biodiesel at 210 bar.

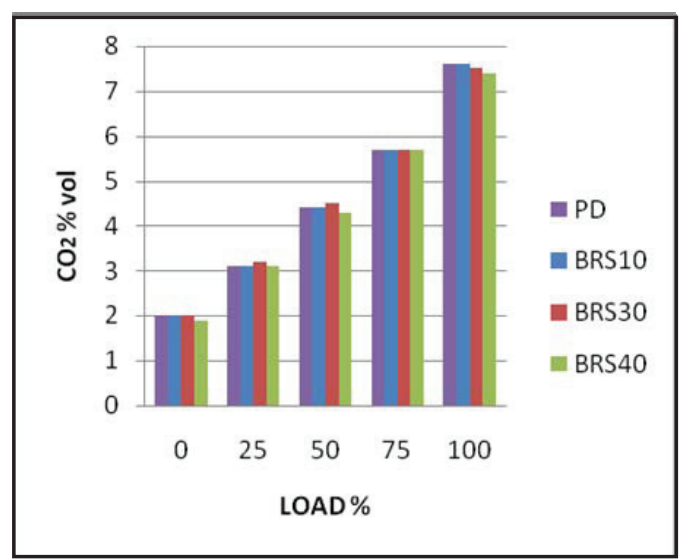

Figure 10. Variation of $\mathrm{CO} 2$ with respect to various blends of biodiesel at 240 bar.

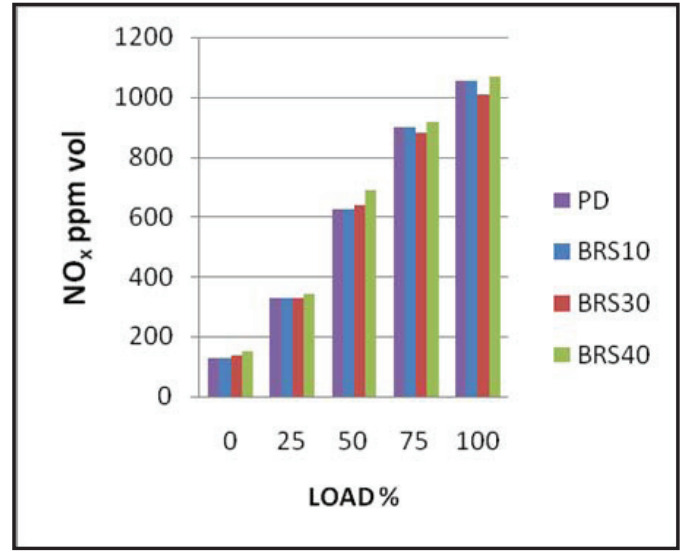

Figure 11. Variation of NOx with respect to various blends of biodiesel at 180 bar.

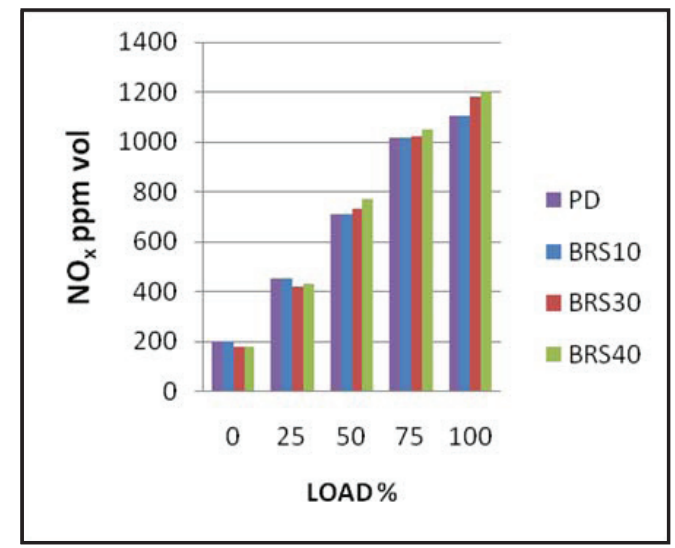

Figure 12. Variation of NOx with respect to various blends of biodiesel at 210 bar.

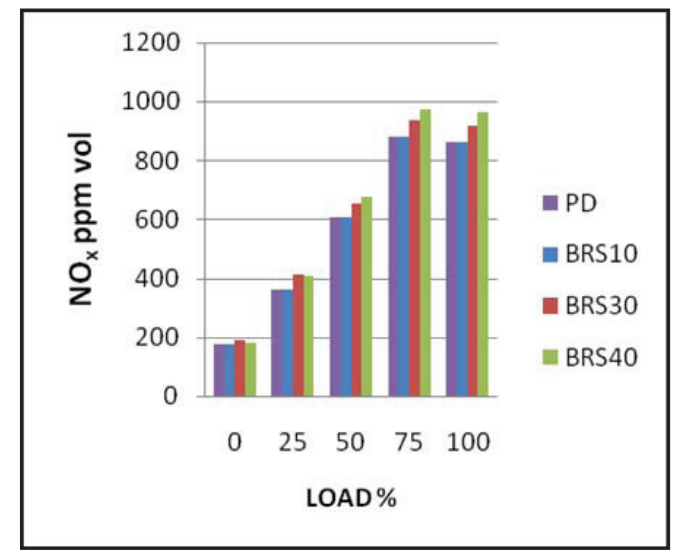

Figure 13. Variation of NOx with respect to various blends of biodiesel at 240 bar. 
In the test conditions, by varying the pressure for variable loads, the emissions studied are discussed below.

\subsection{Carbon mono oxide (CO)}

As seen in the result of three blends shown in Figure 2, 3, 4 , the BRS10 is almost equal to diesel, and for BRS20 and BRS30, the emission of CO increases for different loading at different injection pressures. The efficiency of combustion decreases because of the higher carbon content in rich fuel.

\subsection{Hydrocarbon (HC)}

Figure 5, 6 and 7 shows that there is a better reduction with BRS30 at 180 bar, 210 bar and 240 bar with respect to the various loadings. Tamilvedhan [10] explains, the engine fueled with methyl esters where the mixtures is either too rich to ignite and oxidized fuel in the exhaust this is due to complete combustion. The three hole nozzle is used in the injector which has the reduced size of droplets leading to the better combustion in the cylinder temperature, with increased amount of fuel even at higher loads.

\subsection{Carbon-di-oxide $\left(\mathrm{CO}_{2}\right)$}

Figure $8,9,10$, depicts that there is a marginal increase of CO at 180 bar and better reduction in 210 and 240 bar with $40 \%$ blend. Rakopoulas [3] explains that the required fuel rate is to be higher since the calorific value of vegetable oil is lesser, compared to neat diesel and the subtle distribution of the fuel air packets at different locations are necessary for effective combustion. Three hole nozzle spray at lower pressure from the smaller orifice diameter increases $\mathrm{CO}$ and at the higher injection pressure decreases $\mathrm{CO}$ due to the conversion of carbon atoms to $\mathrm{CO}_{2}$ with enough oxygen which results in better combustion.

\subsection{Nitrous Oxide $\left(\mathrm{NO}_{\mathrm{x}}\right)$}

$\mathrm{NO}_{x}$ emission marginally increases with $30 \%$ and $40 \%$ blend at different injection pressures and various loads whereas at the $10 \%$ of biodiesel blend remains as like diesel. $\mathrm{NO}_{\mathrm{x}}$ is formed due to lower cetane number and higher ignition delay leading to premixed combustion [11]. It could be due to the injection pressure and 3 - hole nozzle splits the fuel particles leading to higher flame temperature which increases $\mathrm{NO}_{\mathrm{x}}$.

\section{Conclusion}

The experiments conducted revealed, that the refined sunflower biodiesel, when blended with diesel by varying the pressure and loading, resulted in desired pattern of emissions. The conclusion are

a. The CO is same at $10 \%$ blend at all loads whereas there is an increase in CO with 210 bar and 240 bar in all blends.

b. The HC emission decreases significantly for $30 \%$ and $40 \%$ blend at different injection pressure, loading as compared with diesel.

c. There is a marginal increase in $\mathrm{NO}_{\mathrm{x}}$, when compared to pure diesel.

d. The reduction in engine temperature of the order of $2^{\circ} \mathrm{C}$, supports the usage of the biodiesel for different engines.

\section{Future Scope of work}

The above analysis can be performed by changing the nozzle angle and nozzle orifice with various profiles and sizes like Elliptical, semi elliptical, etc., in addition to varying the number of nozzles against different blend ratio which may yield higher efficiency with lower emissions.

\section{References}

1. Yin X, Ma H et al. (2012). Comparison of four different enhancing methods for preparing biodiesel through transesterification of sunflower oil, Applied Energy, vol 91(1), 320-326.

2. Onyestyak G, Harnos S et al. (2012). Sunflower oil to green diesel over Raney-type Ni-catalyst, Fuel, vol 102, 282-288.

3. Rakopoulos D C (2012). Heat release analysis of combustion in heavy-duty turbocharged diesel engine operating on blends of diesel fuel with cotton seed or snflower oils and their biodiesel, Fuel, vol 96, 524-534.

4. Shehata M S, and Abdel Razek S M (2011). Experimental investigation of diesel engine performance and emission characteristics using jojoba/diesel blend and sunflower oil, Fuel, vol 90(2), 886-897.

5. Daroda M P, Ballesteras E et al. (2003). Exhaust emissions from a diesel engine fueled with transesteified olive oil, Fuel, vol 82(11), 1311-1315.

6. Tashtoush G, Al-widyan M I et al. (2003). Combustion performance and emissions of ethyl esters of a waste vegetable oil in water cooled furnace, Applied Thermal Engineering, vol 23(3), 285-293. 
7. Sudhir C V, Sharma N Y et al. (2007). Potential of waste cooking oils as biodiesel feed stock, Emirates Journal for Engineering Research, vol 12(3), 69-75.

8. Yusaf T F, Yosif B F et al. (2011). Crude palm oil fuel for diesel engines: Experimental and ANN simlation approaches, Energy vol 36(8), 4871-4878.

9. Shereena K M, and Thangaraj T (2009). Biodiesel: an alternate fuel produced from vegetable oils by transesterification, European Journal of Biochemistry, vol 5(3), 67-74.
10. Tamilvendhan D, and Ilangovan V (2011). Performance, emission and combustion characteistics of a methyl ester sunflower oil - eucalyptus oil in a single cylinder air cooled and direct injection diesel engine, Intenationl Journal of Engineering Science and Technology, vol 3(3), 1977-1985.

11. Ferguson C R, and Kirtpatrick A T (2001). Internal combustion engines-applied thermo scinces, $2^{\text {nd }}$ Edn., Chapter 10, John Wiley \& Sons, Technology Engineering, 318. 